\title{
BARRIERS TO GREEN CITIES DEVELOPMENT IN DEVELOPING COUNTRIES: EVIDENCE FROM GHANA
}

\author{
*Debrah ${ }^{1}$, C., Owusu-Manu ${ }^{2}$ D., Kissi ${ }^{3}$, E., Oduro-Ofori ${ }^{4}$, E., and Edwards ${ }^{5}$, D.J. \\ ${ }^{1}$ Teaching and Research Assistant; Department of Construction Technology and \\ Management, Kwame Nkrumah University of Science and Technology, Kumasi, Ghana.
}

Email: cal.debrah@gmail.com

${ }^{2}$ Associate Professor; Department of Construction Technology and Management, Kwame Nkrumah University of Science and Technology, Kumasi, Ghana.

Email: $\underline{\text { d.owusumanu@gmail.com }}$

${ }^{3}$ Lecturer; Department of Construction Technology and Management, Kwame Nkrumah University of Science and Technology, Kumasi, Ghana.

Email:kisernest@gmail.com

${ }^{4}$ Senior Lecturer; Department of Planning, Kwame Nkrumah University of Science and Technology, Kumasi, Ghana. Email:_odurooforieric@yahoo.com

${ }^{5}$ Professor; School of Engineering and the Built Environment, Birmingham City University, United Kingdom and

Faculty of Engineering and the Built Environment,

University of Johannesburg, South Africa

Email: drdavidedwards@aol.com

*Corresponding Author.

\begin{abstract}
Purpose: Of late, cities across the globe are taking pragmatic steps towards addressing environmental, social, and economic problems in the debate on sustainable development. Even so, little attention has been paid to studies focused on developing countries. The aim of this study is to examine the barriers to green cities development in developing countries.

Design/Methodology/Approach: A comprehensive literature review was conducted to examine the barriers to green cities development. In terms of methodological choice, a quantitative research strategy was used to collect data from professionals who have lines of influence on the greening of our cities and sustainable urban development.
\end{abstract}


Findings: The barriers to green city development identified were: Lack of awareness of the benefits of a green city, Environmental Degradation, Insufficient policy implementation efforts, Excessive generation of solid waste, and Poor wastewater collection and treatment. It was indicative from the study findings that taking the right sustainable steps in urban development and a paradigm shift towards the pillars of sustainability, Ghanaian cities especially Kumasi has a great proclivity of regaining its longstanding status being "Garden City".

Practical and theoretical implications: The outcome of this study provides stakeholders in city development an insight into the barriers that inhibit the development of green cities. In practice, this study contributively proposes that the concept of green cities should be incorporated in the education and training of stakeholders to improve the level of awareness.

Originality/value: This paper presents the foremost comprehensive study appraising green city development in Ghana.

Keywords: Ghana, Green Cities, Barriers, Sustainable Cities, Sustainable Development, Urbanisation.

Paper type: Research Paper

\section{Introduction}

Cities are centres for worldwide transformation and continue to wield their global impact (Hoornweg and Freire, 2013). According to UN (2018), the population living in cities or urban areas was $41 \%$ in lower-middle-income countries and $32 \%$ in low income countries. The Sub-Saharan Africa (SSA) has experienced the highest urban growth since the 1990s at an average rate of 3.5\% per year (Mclntyre et al., 2009). Accra (Ghana), Lagos (Nigeria), and Libreville (Gabon) among major cities in the SSA are characterised by high rates of urbanisation which have led to upsurges of unplanned urban cities (McIntyre et al., ibid). Urbanisation and industrialisation have contributed to the deterioration of the environment through the reduction of environmental performance, reduced water quality and quantity, obliteration of urban natural resources and green fields, fuel consumption, traffic congestion leading to increased journey time (Organisation for Economic Co-operation and 
Development (OECD), 2013). Rosenzweig et al. (2018) attributed 70\% of greenhouse gas emissions in cities to urban transport. It is evident from the data presented that there is an upsurge in global population and therefore there is the need for measures to sustain urbanisation (Authors Emphasis). Sustainable development meets the needs of the present without compromising the ability of future generations to meet their own needs (World Commission on Environment and Development (WCED), 1987). Jabareen (2006) asserted that after the advent of sustainable development as a popular concept, the discourse on the form of cities has been heightened. Brilhante and Klass (2018) observed that many ideas and approaches attempt to manage city growth without undermining sustainable development. Extant literature has paid attention to sustainable city designs amidst pollution, environmental impact, energy usage, the effects of climate change resulting from urbanisation (Jabareen, 2006; Hoornweg and Freire, 2013). Hoornweg and Freire (2013) furthered that cities are becoming leaders, globally, in steps towards addressing global environmental and social problems.

Cities make a significant contribution to global issues, including climate change and depletion of biodiversity. Keivani (2010) viewed that the contemporaneous focus on climate change is indubitably warranted considering the existential peril global warming poses to the world. Green cities are critical to sustainable development, given their status as engines of economic growth, centres of population growth and resource consumption as well as receptacles of culture and innovation (Hoornweg and Freire, 2013). To make urban areas green demand the need to address the research and knowledge gaps, increase stakeholder participation and promote behavioural or psychological change at the individual, corporate, local and public levels (Hoornweg and Freire, 2013), an important conception for sustainable development. Furthermore, Jabareen (2006) in a study identified sustainable 
(green) urban (city) forms and their design concepts by perusing the capability of certain urban forms to contribute to sustainability than others.

Extant literature in Ghana has focused more on the development of green buildings (Ayarkwa, 2017; Anzagira et al., 2019); success factors of green building (Kats, 2003), drivers and barriers green building technologies (Darko et al., 2017); benefits of green buildings (Darko et al., 2018) among others. The idea and concept of green building has not been fully incorporated into construction practice in Ghana (Ayarkwa, 2017; Darko et al., 2017; Anzagira et al., 2019). This further inhibits the idea of a green city in Ghana. From the foregoing, a dearth of knowledge or research works focused on the evolution and development of green cities in developing countries especially Ghana is evident. Darko et al. (2017) affirmed that the adoption and advancement of green building technologies in Ghana is slow and infantile. Despite the growing interest in the concept of green city towards the augmented implementation of green buildings, it is lucid that little attention has been paid to studies focused on developing countries. This study is clearly posited to bridge the identified knowledge gap in the advancement of the green city concept in Ghana. The aim of this study is to examine the barriers to green cities development in developing countries. This study will contribute to growing knowledge available to Ghana in the promotion and achievement of sustainable and eco-friendly cities towards the realisation of SDG Goal 11 by 2030.

\section{The Debate of Green Cities on Research Space}

According Ayarkwa et al. (2017), urbanisation and industrialisation are having a great impact on the earth's ecosystems as a result of environmental degradation, pollution, climate change and poverty globally inclusive of Ghana. Haruna et al. (2018) reported that Ghana is facing major climate change and environmental problems within cities with frequent and fatal events of floods as well as gross pollution and degradation of the natural environment including soil and water ways. Extant literature agrees that there is a symbiotic relationship between 
urbanisation and environmental problems leading to the growing concern in the debate on climate change. The development of cities in SSA especially in Ghana is overwhelmed with overpopulation and unsustainable practices. According to Liaros (2019), Ecocities, EcoVillages, Green Cities, Livable Cities, Biophilic Cities, Smart Cities has been the talk of city development over the years and a major source of concern for many. Green cities are seen as pivotal to city development under the SDGs. The concept of "green city" or "green development" is not novel (Lewis, 2015). According to the UN (2015), the Sustainable Development Goals (SDGs) embrace the concept of making cities as an integral aspect of attaining eco-friendlier and more sustainable futures for this generation and posterity. A green city is a holistically planned new settlement which enhances the natural environment and offers high-quality affordable housing and locally accessible work in beautiful, healthy and sociable communities (Simon, 2016). Various authors in current studies agree that green cities or infrastructure is a cogent strategy targeted at mitigating and adapting to the effects of climate change (Onishi et al., 2010).

\section{Barriers to Green Cities Development}

For decades, urban policy and strategy has been dominated by thinking about the physical city: more productive and greener cities, landmark architecture, transport, increasingly the technological infrastructure to create smarter, urban development and housing. World Economic Forum (2016) stated that cities today must: plan for a sustainable and resilient future; balance economic and social development in addition to environmental protection; and design solutions adapted to their local contexts and enhance their character. Chan et al. (2018) emphasised in a recent study that green building technologies have been advocated in the construction industry to address sustainability issues. Anzagira et al. (2019) avow that green building concept has been well received by governments around the world as a strategy for improving the sustainability of the construction industry. Adaptation of cities to climate 
change had not been a prominent issue in academic and political debate on societal responses to global climate change for years (Huq et al., 2007).

Green Growth Best Practice Initiative (2014) advanced that one of the basic challenges to urban green growth policies is restoring environmental quality. According to UN Habitat (2013), many cities especially in developing countries have experienced rapid economic and demographic growth and have built up issues related to water, air pollution, land degradation and noise pollution. UN Habitat (ibid) reported that 33-50\% of the solid waste generated by cities in low-and-middle income countries is not collected and less than $35 \%$ of waste water is treated. Sandhu et al. (2010) added that social challenges like the inability of households in India to afford market-price rents is estimated to be of 38 million in their cities. Costa et al. (2008) added that the incidence of long-term natural processes that are involved in the growth and maturation of the living elements; and the fact they represent public values and have an important role to play for the well-being and health of the inhabits as some challenges for an urban green space strategy.

London School of Economics (LSE) (2013) categorised the challenges of green cities in 5 constructs: (1) Finance (financial budget limitations; maintaining the revenue and tax base; financial constraints due to high debt loading; revenue shortfalls and financing infrastructure) (2) Housing (affordable housing; homelessness; building social housing; slums; building housing with good environmental standards; and meeting the housing needs of all income levels); (3) Population growth (demands of rapid growth; accommodating an increasing population; rapid urbanisation; demographic challenges; and the challenges of a fast growing city); (4) Jobs (creating jobs; long-term unemployment; local family wage; jobs; jobs retention; and quality job growth); (5) transport (increase in private vehicles; incomplete public transport network; congestion; developing an integrated transport system; accessibility and urban mobility). Mersal (2017) acknowledged that some challenges of green city 
development are socio-economic and demographic factors. Ichimura (2003) stressed that some of the socio-economic and demographic factors include increase of population of cities, congested traffic, lack of infrastructure, environmental degradation and a housing short-age. Persistent in the development of cities is environmental issues related to urban sprawl being low density and fragmented, separated land use, car centric development (Leichenko and Solecki, 2005). International investment laws, profit-seeking agendas of investors, protecting of interest in land by local communities (i.e. land ownership, quality of the environment and livelihood opportunities) are some of the challenges to present day green city development (Tan-Mullins, 2018). Some barriers identified by Zhang et al. (2011) in the application of green elements include: interests or conflicts between stakeholders in the usage of green measures, high green appliance design and energy saving material costs, unfamiliarity with green technologies leading to delays in the design and whole construction process, insufficient policy implementation efforts, lack of integrated efficiency for city regulations and byelaws within the green framework, lengthy planning and approval process for new green technologies and recycled materials, and risks involved in varied contract forms in project delivery.

\section{Research Methodology}

A comprehensive literature review was conducted to examine the barriers to green cities development. This study adopted the pragmatism as its undergirding research philosophy consistent with Saunders et al. (2009). The study adopted the deductive research approach as the means of scientific inquiry and reasoning to test whether data is consistent with prior assumption, theories or hypothesis identified or developed by the researcher (Thomas, 2006). In terms of methodological choice, the quantitative methods research strategy was used for this study with the aid of statistical analysis (Johnson and Onwuegbuzie, 2004). 
The population for this study included the agencies of the state who have lines of influence on the greening of our cities and sustainable urban development and green city experts. Due to the challenges encountered in evaluating the population size due to a lack of data of green city/sustainability experts in Ghana, the study adopted the non-probability sampling techniques adopted in Owusu-Manu et al. (2018) in the determination of the sample size. The purposive and snowballing sampling techniques were thus adopted for the study. In purposive sampling, the researcher decides what needs to be known and sets out to find participants who can and are willing to be part of the study by dint of knowledge and experience (Lewis and Sheppard, 2006). Neville (2007) stressed that snowball builds up a sample through informants - it starts with one person who then suggests the next respondent and the trend continues. A sample is adequate when the all information needed for the study has been obtained. The sample size for the study was thus 200 experts in city development and were abreast with sustainability issues (i.e. Surveyors, Construction Managers, Architects, Sustainability Lecturers, Project Managers, Engineers, Energy experts, Security Analysts and experts, Health and Safety Officers, Finance experts, Development practitioners, Environmental Officers, Urban and Development Planners, District/Municipal/Metropolitan Directors).

\section{Survey Administration}

This study adopted the descriptive research design by using the case study and survey instrument. In this regard, a self-administered structured questionnaire survey questionnaire was adopted (through a combination of an online survey and the drop-and-pick method). The questionnaire was divided in two main sections. Section I of the instrument targeted the demographic profiles of the respondents. This was necessary to authenticate the capacity of the respondents to partake in the study and help to caution the researcher to gather more data to avoid respondent biases (Pandey and Pandey, 2015). Section II examined the barriers to green cities development in developing countries towards the ultimate achievement of the 
aim of the study. Respondents were asked to rank the variables identified through the literature review using the 5-point Likert scale ranging: 1(Not Severe), 2(Less Severe), 3(Moderately Severe), 4(Severe), 5(Very Severe). The data was distributed through an online survey and mails (118 respondents) and by using the drop-and-pick method (36 respondents). A total of 154 questionnaires were retrieved out of the 200 target respondents accounting for $77 \%$ response rate. The web-based surveys and the drop-and-pick method have become popular in self-administered questionnaires (SAQ) and has been used in extant literature to achieve high response rates (Jackson et al., 2016). The high response rate of $77 \%$ due to an intensive follow-up technique was considered adequate. A response rate of $60 \%$ was considered adequate, acceptable or marginal, $70 \%$ is reasonable or preferable, $80 \%$ is desirable or good and 90\% is excellent in surveys (Davidoff et al., 2002).

\section{Test for reliability and validity}

The reliability of the scale and internal consistency of the variables was checked by using the Cronbach's Alpha Coefficient test. A scale is considered reliable if the Cronbach Alpha test results in a co-efficient of 0.700 or greater (Muijs, 2010). A Cronbach's Alpha of 0.936 for the study is thus reliable for further analysis.

Furthermore, the validity of the questionnaire was tested through a pilot study (Mathers et al., 2007) that involved 9 respondents out of 10 sampled. The pilot survey was to find out if the identified barriers from the literature review was suitable for the larger population or truly represented barriers to green cities development particularly in Ghana (cf. Kissi et al., 2020b). Furthermore, the pre-testing aided the researchers in clearing any ambiguities and ensuring that the questions posed measured what was intended. The 9 respondents were: Health and Sanitation Expert, a Built Environment Lecturer (Sustainability), Construction Engineer, Planning Officer, Assistant Research Professor (Green Building Expert), Quantity Surveyor, Municipal Director, Architect, and Development Practitioner. Moreover, factor 
loadings have been employed in extant literature to determine the construct validity of data collected for a study (Mujis, 2010). Loadings of greater than 0.50 is considered valid (Guadagnoli and Velicer, 1988). The factors loadings for the variables ranged 0.42 to 0.86 . A few variables recorded factors loadings below the acceptable 0.50 .

\section{Data Analysis}

The primary data retrieved from the study were analysed using Descriptive Statistics (Means, Frequencies and Standard Deviations) and Inferential tools (One-sample t-test, and Relative Importance Index). Software used for the analysis included the Statistical Package for Social Sciences (SPSS) windows version 21; and the R Project for Statistical Computing. According to Muijs (2010), the SPSS is the most common statistical data analysis software package used in educational research.

Relative Importance Index (RII) allows the identification of the most important criteria based on the responses of the participants of the survey and it is also an appropriate tool to prioritise the indicators (Rooshdi et al., 2018) rated on the Likert scale adopted for the study. The RII was calculated using the formula below as adopted by Owusu-Manu et al. (2019). [W weighting given to each statement by the respondents ranging 1 to 5; A - higher response integer (5); $\mathrm{N}$ - total number of respondents].

$$
\mathrm{RII}=\frac{\sum W}{\mathrm{~A}^{*} \mathrm{~N}}
$$

The descriptive statistics described the relationship between variables in a sample population. Regarding descriptive statistics this study is described by the measures of central tendency and degrees of dispersion (SD) as proposed by Ali and Bhaskar (2016).

One Sample T-test is a statistical procedure used to examine the mean difference between the sample and the known value of the population mean. In one sample t-test, the population mean is known (Lani, 2016). 


\section{Descriptive Analysis of Respondents Demographic Profile}

This section was targeted to validate the responses elicited for the study. Respondents were asked to assess the predisposition of Kumasi city being dubbed a green city. $75 \%$ of the respondents viewed that Kumasi city has the proclivity of becoming green with its characteristic nature of multidimensionality; high environmental performance; human wellbeing; responsible society; environmentally friendly and being ranked among the current green cities like London, Sao Paulo, New York, Delhi, Lagos, Mexico City, Berlin, Johannesburg, Shanghai and Buenos Aires (Lewis, 2015; Brilhante and Klaas, 2018).

From Table I, it is evident that majority of the respondents have experience between the years of $1-5$ years. Work experience has been perceived to guarantee the quality and quantity in the performance of a specific task. According to Leksakundilok (2004) a varied experience is to ensure that they can be the representation of what represents the community or city.

\section{Table I. Demographic Data of Respondents}

\begin{tabular}{lll} 
Area of Expertise & Frequency & Percent \\
\hline \hline Business and Finance & 14 & 9.1 \\
\hline Governance & 16 & 10.4 \\
\hline Infrastructure and Planning & 52 & 33.8 \\
\hline Health and Safety & 9 & 5.8 \\
\hline Environment, Water and Sanitation & 19 & 12.3 \\
\hline Education & 27 & 17.5 \\
\hline Energy and Security & 17 & 11.0 \\
\hline Years of Experience & & 46.1 \\
\hline \hline 1-5 years & 71 & 32.5 \\
\hline 6-10 years & 50 & 13.0 \\
\hline 11-15 years & 20 & 8.4 \\
\hline 16-20 years & 13 & 54.5 \\
\hline Academic Qualification & & 36.4 \\
\hline \hline Bachelor's Degree (BSs/BA/BEd) & 84 & 9.1 \\
\hline Master's Degree (MSc/MPhil/MA/MBA) & 56 & 1.3 \\
\hline Doctoral Degree (PhD/DBA) & 14 & 11.7 \\
\hline \hline Familiarity with the green city concept & & \\
\hline Not at all & 2 & 18 \\
\hline Somewhat & & \\
\hline & & \\
\hline
\end{tabular}




\begin{tabular}{lll} 
Familiar & 72 & 46.8 \\
\hline Very Familiar & 49 & 31.8 \\
\hline Expert & 13 & 8.4 \\
\hline \hline Total & $\mathbf{1 5 4}$ & $\mathbf{1 0 0 . 0}$ \\
\hline \hline
\end{tabular}

Table I shows the area of expertise of the respondents after data cleaning and coding Governance, Infrastructure and Planning, Environment, Water, And Sanitation, Business and Finance, Health and Safety, Energy and Security, and Education - from the 154 retrieved responses. It evident that majority of the respondent were Infrastructure and Planning experts (33.8\%), closely followed by Educationist - Sustainability related (17.5\%). The varied level of respondent expertise adopted for this study is consistent with Hammer (2011) who asserted that green city development should be assessed from technical, stakeholder and political aspects.

As part of determining the capacity of the respondents to understand the survey and to determine the credibility, respondents were required to indicate their highest level of academic qualification. $54.5 \%$ of the representing the majority had attained at least a Bachelor's Degree or higher. This is consistent with Hegarty et al. (2011) who asserted that academic qualification can help to gain more knowledge for professional development and organisational development.

Furthermore, respondents were required to indicate their level of familiarity with the concept of a green city. It can simply be deduced that $8.4 \%$ of the 154 respondents identified themselves as experts in the green city concept. As experts, they could be seen as individuals who have ideas, experiences or even policies about the implementation, benefits and challenges of green cities, and could easily provide recommendation for improvement in the concept. However, majority of the respondents were familiar (46.8\%) and very familiar (31.8\%) with the green city concept. Just a handful of the respondents (1.3\%) had no 
knowledge or familiarity with the green city concept. It was obvious from the level of familiarity of the respondents to provide credible data on the sustainable development considerations of a green city concept.

\section{Understanding the Barriers to Green Cities Development in Developing Countries}

The Mean Score Rank and the Relative Importance Index (RII) were used analyse the responses from the field survey. The standard deviation and standard error were determined to ascertain the level of agreement of the responses given. Also, the normality of the data was checked by using univariate skewness and kurtosis in the analysis. Kline (2015) iterated that the normality of data could be confirmed by using univariate skewness and kurtosis if the absolute value of the skewness and kurtosis is less than 3.0 and 8.0 respectively. By inspection, Table II confirms that the study had a good normality of data.

Consistent with extant literature, the barriers that inhibited the development of green cities were examined and the ranking of the attributes in relation to their level of severity as perceived by the respondents was done using the RII as shown in Table II. In agreement with Owusu-Manu et al. (2019) and Kissi et al. (2020a) where two or more variables have the same RII, the variable with the highest mean is ranked higher. Moreover, where two or more variables have the same mean, the one with the lowest standard deviation is given the precedence in terms of ranking. This is because standard deviation measures the consistency of agreement between the respondents' interpretation, and hence, the lower the standard deviation number the better (Altman and Bland, 2005; Ahadzie, 2007; Owusu-Manu et al., 2019).

Lack of awareness of the benefits of a green city was highly ranked by the respondents as the foremost barrier that militate against the development of a green city recording an RII of 
0.77, a high mean score of 3.86 and an SD of 1.153. Closely ranked was Environmental

Degradation with an RII of 0.77 but a lower mean score of 3.84 and an SD of 1.087. Insufficient policy implementation efforts [RII=0.76; Mean=3.81 and $\mathrm{SD}=0.922]$, Excessive generation of solid waste $[\mathrm{RII}=0.76$; Mean=3.80 and $\mathrm{SD}=1.233]$, and Poor waste water collection and treatment $[\mathrm{RII}=0.75 ;$ Mean $=3.75$ and $\mathrm{SD}=1.168]$ ranked third, fourth and fifth respectively.

The least ranked barriers were Noise Pollution [RII=0.63; Mean=3.17 and SD=1.159], Low income of household [RII=0.63; Mean=3.13 and $\mathrm{SD}=1.147]$ and Long-term natural process of living elements [RII=0.60; Mean=3.00 and $\mathrm{SD}=1.023$ ]. These barriers recorded lower RII and Mean Scores and were seen to be insignificant barriers that inhibit the development of Green Cities.

Table II. Relative Importance Index of the Barriers to Green Cities Development S/N Barriers Mean Std Err. Std. Dev. Skewness Kurtosi

1. Lack of awareness of the 3.86 0.094 1.153 $-0.947$ 0.187 $0.77 \mathbf{1}^{\text {st }}$ benefits of a green city

2. Environmental Degradation

3. Insufficient policy 3.84 0.088 1.087 $-1.062$

0.723

0.77
implementation efforts

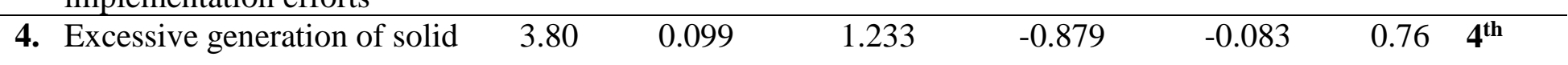
waste

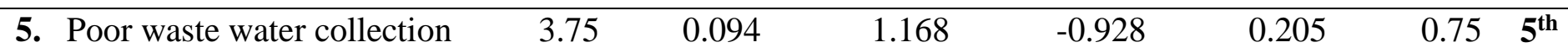
and treatment

6. Financial Constraints and

$3.72 \quad 0.080$

0.993

$-0.386$

$-0.355$

0.74 6 $^{\text {th }}$ revenue shortfalls of the government

7. Congestion of cities (e.g. carcentric development)

8. Excessive Population growth

9. Development of Slums

$3.71 \quad 0.096$

1.193

$-0.796$

$-0.124$

$0.747^{\text {th }}$
regulations and byelaws within 3.61

$3.65 \quad 0.093$

$3.62 \quad 0.095$

1.152

$-0.631$

1.178

$-0.552$

$-0.338$

$0.73 \mathbf{8}^{\text {th }}$
the green framework

$\begin{array}{llllllll}\mathbf{1 1} \text { Air Pollution } & 3.53 & 0.094 & 1.173 & -0.556 & -0.310 & 0.71 & \mathbf{1 1}^{\text {th }} \\ \begin{array}{l}\mathbf{1 2} \text { Profit-seeking agendas of } \\ \text { investors }\end{array} & 3.52 & 0.077 & 0.951 & -0.472 & .129 & 0.70 & \mathbf{1 2}^{\text {th }}\end{array}$

13 Conflicting interest of

3.42

0.083

1.033

$-0.221$

$-0.526$

$0.6813^{\text {th }}$


stakeholders in the usage of

green measure

14 Community Resistance to

$\begin{array}{lll}3.39 & 0.088 & 1.087\end{array}$

$-0.177$

$-0.693$

$0.6814^{\text {th }}$ green city development

15 Incomplete public transport network

16 Homelessness or housing shortage

17 Increasing in the private vehicles

18 Noise Pollution

$3.38 \quad 0.093$

1.155

$-0.287$

$-0.701$

$0.6815^{\text {th }}$

$3.31 \quad 0.095$

1.173

$-0.247$

$-0.738$

$0.6616^{\text {th }}$

$3.27 \quad 0.090$

1.120

$-0.063$

$-0.667$

$0.6517^{\text {th }}$

19 Low income of household

3.17

0.093

1.159

59

$-0.310$

$-0.636$

$-0.126$

$-0.727$

\begin{tabular}{ll}
0.63 & $18^{\text {th }}$ \\
\hline 0.63 & $19^{\text {th }}$ \\
0.60 & $20^{\text {th }}$
\end{tabular}

$20 \begin{aligned} & \text { Long-term natur } \\ & \text { living elements }\end{aligned}$

0.082

1.023

$-0.111$

$-0.499$

Source: Field Survey (2020)

\section{One-Sample T-test}

A further One-Sample t-test was done to ascertain the level of significance of the barriers.

One Sample t-test is a statistical procedure used to examine the mean difference between the sample and the known value of the population mean. The one sample t-test is used to establish the relative significance of the variables (Ross and Willson, 2017; Owusu-Manu et al., 2018; Kissi et al., 2020a). In agreement with Ahadzie (2007) and Ross and Willson (2017), the one-sample t-test reported the degrees of freedom for the test (an approximate of the sample size), the test value (the strength of the test), and the p-value (probability of the test being significant). At $95 \%$ confidence level with a p-value of less than 0.05 , and a test value of 3.5 (hypothesised mean), the one sample t-test was adopted to further determine the significance of the factors to the study. In this study, the null hypothesis (Ho) is that "the mean value is not statistically significant barrier" whilst the alternative hypothesis (Ha) means that "the mean value is a statistically significant barrier". Consistent with OwusuManu et al. (2018), the 95\% confidence level interval estimated the difference between the population mean weight and the test value (3.5). For each variable, the null hypothesis was that the variable was not a significant factor $(\mathrm{Ho}: \mathrm{U}=\mathrm{Uo})$. Uo is the critical rating above which the variable is considered to be important. The p-value is the probability that the random 
variables takes on values that a farther away from the mean assuming the null hypothesis is true. Thus, the p-value was used to determine whether or not to reject the null hypothesis (Massey and Miller, 2006; Kissi et al., 2020a). Impliedly, the null hypothesis was not rejected once the p-value is less than 0.05 in using one sample T-test (Ross and Willson, 2017; Owusu-Manu et al., 2018).

The factors that had positive t-values (strength of the test) were indicative that their means were significantly above the hypothesised mean. Those with negative t-values were rejected. Furthermore, all the barriers with a p-value (significance of the test) less than 0.05 were significant to the study implying that the means of these variables are not significantly different from the hypothesised mean of 3.5.

Table III. One Sample T-test

Test Value $=3.5(95 \%$ Confidence Level $)$

\begin{tabular}{rlrccc} 
& & & & Null \\
\cline { 3 - 5 } S/N & Barriers & $\boldsymbol{t}$ & $\boldsymbol{D f}$ & $\boldsymbol{p}$ & Hypothesis \\
\hline \hline 1. & Lack of awareness of the benefits of a green city & 3.853 & 153 & 0.000 & Not rejected \\
\hline 2. & Environmental Degradation & 3.850 & 153 & 0.000 & Not rejected \\
\hline 3. & Insufficient policy implementation efforts & 3.005 & 153 & 0.002 & Not rejected \\
\hline 4. & Excessive generation of solid waste & 4.106 & 153 & 0.000 & Not rejected \\
\hline 5. & Poor waste water collection and treatment & 2.691 & 153 & 0.004 & Not rejected \\
\hline 6. & $\begin{array}{l}\text { Financial Constraints and revenue shortfalls of the } \\
\text { government }\end{array}$ & 2.758 & 153 & 0.003 & Not rejected \\
\hline 7. & Congestion of cities (e.g.car-centric development) & 2.161 & 153 & 0.016 & Not rejected \\
\hline 8. & Excessive Population growth & 1.609 & 153 & 0.055 & Not rejected \\
\hline 9. & Development of Slums & 1.231 & 153 & 0.110 & Rejected \\
\hline 10. & $\begin{array}{l}\text { Non-alignment of city regulations and byelaws } \\
\text { within the green framework }\end{array}$ & 1.354 & 153 & 0.089 & Rejected
\end{tabular}




\begin{tabular}{|c|c|c|c|c|}
\hline 11. Air Pollution & 0.275 & 153 & 0.392 & Rejected \\
\hline 12. Profit-seeking agendas of investors & 0.254 & 153 & 0.400 & Rejected \\
\hline $\begin{array}{l}\text { 13. Conflicting interest of stakeholders in the usage of } \\
\text { green measure }\end{array}$ & -1.014 & 153 & 0.844 & Rejected \\
\hline 14. Community Resistance to green city development & -1.261 & 153 & 0.895 & Rejected \\
\hline 15. Incomplete public transport network & -1.325 & 153 & 0.907 & Rejected \\
\hline 16. Homelessness or housing shortage & -2.060 & 153 & 0.980 & Rejected \\
\hline 17. Increasing in the private vehicles & -2.589 & 153 & 0.995 & Rejected \\
\hline 18. Noise Pollution & -3.545 & 153 & 1.000 & Rejected \\
\hline 19. Low income of household & -4.003 & 153 & 1.000 & Rejected \\
\hline 20. Long-term natural process of living elements & -6.068 & 153 & 1.000 & Rejected \\
\hline
\end{tabular}

Source: Field Survey (2020)

Lack of awareness of the benefits of a green city $(\mathrm{t}=3.853$; sig. $=0.000)$; Environmental Degradation $(\mathrm{t}=3.850$; $\operatorname{sig} .=0.000)$; Insufficient policy implementation efforts $(\mathrm{t}=3.005$; sig.=0.002); Excessive generation of solid waste $(\mathrm{t}=4.106$; sig. $=0.000)$; and Poor waste water collection and treatment $(\mathrm{t}=2.691 ;$ sig. $=0.004)$ were significant to the study as shown in Table III. Other barriers like Development of Slums; Non-alignment of city regulations and byelaws within the green framework; Air Pollution and Profit-seeking agendas of investors had positive $t$ values but their $p$ values were higher than the accepted $p<0.05$, hence were insignificant to the study. The other barriers had negative t-values and insignificant $p$-values.

\section{Discussion of Findings}

Lack of awareness of the benefits of a green city was the highly ranked barrier to Green City Development. It can thus be asserted that the most severe barrier to green city development is the lack of awareness of the benefits of a green city. The adoption of green city development is a multi-faceted aspect of urban development that demands various stakeholders to know of the varied long-term benefits associated with green cities in the light of sustainable development. Nonetheless, lack of knowledge or awareness of such benefits could impede the 
development of green city therewith. This is consistent of various authors who agree that the major barrier of green development is lack of awareness of the benefits (Windapo and Goulding, 2015; Barthel, 2016; Mersal, 2017). In a study by AlSanad (2015) in Kuwait, lack of awareness was identified as the major barrier to green and sustainable construction. In a review of the barriers to green building development, Darko and Chan (2017) stressed lack of awareness, knowledge and education as a major barrier.

Environmental Degradation ranked as second barrier to Green City Development. Continuous degradation of the land (nature) rids the benefits of sustainable development and the gains of a future green city vanish into the glim. Consistent with extant literature, Ichimura (2003) identified environmental degradation as an inhibition to green city development.

Insufficient policy implementation efforts ranked as the third most severe barrier that militates against the development of green city development. Barthel (2016) acknowledged on the lack of environmental regulations at the national level and the copy and paste of international standards are serious limits of the approach to eco-urbanism or green cities in Morocco. Other major barriers that militate against green city development include Excessive generation of solid waste, Poor waste water collection and treatment and Financial Constraints and revenue shortfalls of the government. Consistent with current literature, Zhang et al. (2011) identified interests or conflicts between stakeholders in the usage of green measures, lack of integrated efficiency for city regulations and byelaws within the green framework, lengthy planning and approval process for new green technologies and recycled materials as some barriers to green city development in a study. Tan-Mullins (2018) also asserted profit-seeking agendas of investors, protecting of interest in land by local communities (i.e. land ownership, quality of the environment and livelihood opportunities) are some of the challenges to present day green city development. The barriers identified in this study were consistent with a study by LSE (2013) where the challenges of green cities 
were categorised under five constructs: transport; jobs; population growth; housing and finance.

The findings of the study are comparable to a similar study conducted in eco-districts in France (more than 10) and other European cities. The challenges to sustainable city development were related to mobility, energy, comfort aesthetics and well-being, air quality, water management, biodiversity and nature (cf. Boquet et al. (2020). Consistent with TanMullins' case study of the Sino-Singapore Tianjin Eco-city revealed some barriers to green city development to include conflicting interests and mandates of stakeholders (cf. TanMullin, 2018). Environmental externalities (emissions, degradation), lack of government regulations and lack of robust regulatory implementation were identified as part of the challenges to green city development based on studies in Sino-Singapore Tianjian, Caofeidian and Dongtan Eco cities (Zhou, 2007; Lindfield and Steinberg, 2012).

\section{Contributions to Theory}

The significance of this study is measured in terms of the level of contribution to theory, practice and managerial implications. The significance of this study is consistent with Darko et al. (2018) who emphasised that the area and concept of green development would continuously be of great interest to researchers, practitioners and policy makers. Theoretically, this study adds to the growing knowledge on sustainability, green development, sustainable urban development, eco-city, green city, and sustainable cities which aligns with the UN SDGs. Green Cities in Ghana is discussed in the light of an innovative approach to city development that must be approached holistically by engaging all aspects of social, environmental and economic development through the engagement of the various stakeholders in sustainable urban development. This study adds up to theories addressing sustainability issues especially in Ghana by focusing on the barriers that militate against the development of green cities in Ghana. This study adds to the understanding of the 
concept of green city development in Ghana and SSA. The finding of the study stirs up the debate in sustainable urban development and further benefits the academia by setting the course for continuous discussion on green cities in Ghana and SSA at large. This will also serve as a source empirical data to motivate others to conduct further research. The level of awareness of the green city concept in Ghana is expanded in this study and builds on the knowledge of green or sustainable urban development that can be adopted for green city development in Ghana. In agreement with Prakash (2019), the findings of this study will contribute to shaping significant learning of green city development in developing countries especially Ghana.

\section{Contributions to Practice and Policy}

This study made substantial contribution to industry practice and policy makers in the field of green cities and urban sustainability. This study provides guidelines to policy makers on the shift globally to green cities towards the resultant achievement of the UN SDGs on sustainable cities by 2030. The outcome of this study provides stakeholders of development an insight into the barriers that inhibit the development of green cities. It was clear from the study findings that the level of expertise in green city development must be improved through constant education and training in sustainable city development or green cities as majority of the respondent were either familiar or very familiar with the green city concept. In practice, this study contributively proposes that the concept of green cities can be incorporated in the education and training of stakeholders to improve the level of awareness of the numerous benefits associated with green city development on the environment, society and the economy. Policy implementation should be geared towards reducing unsustainable urban practices and incentivising sustainable behaviour in citizens. Green city development should be community-involving to avert community resistance to green city development. The findings of the study further confirm that the barriers prevalent in developing countries and 
the developed world through the development of their green cities are consistent. It is clear that when these barriers are addressed in the budding green city concept in developing countries especially Ghana, the success achieved in green cities globally can be attained as well.

\section{Conclusion, Limitations and Future Work}

This study reported on the results of a quantitative survey on the barriers to green cities development in developing countries. The severe barriers that were identified from the study to militate against green cities development were Lack of awareness of the benefits of a green city; Environmental Degradation; and Insufficient policy implementation efforts. It is indisputable that the green city concept in SSA and Ghana is nascent. Nonetheless, the green city concept is enormously beneficial to the development of a growing African and Ghanaian economy in terms of planned new settlement, enhancing the natural environment, offering high-quality affordable housing and locally accessible work in beautiful, healthy and sociable communities. This study extends extant literature and the discussion in the direction of sustainable urban development by presenting a holistic and insightful discussion on the barriers that militate against green city development in developing countries with a focus on Ghana. It was indicative from the study findings that taken the right sustainable steps in urban development and a paradigm shift towards the pillars of sustainability, Ghanaian cities especially Kumasi has a great proclivity to being dubbed as a "Green City". The novelty of this study is evident in the presentation of empirical barriers that militate against green city development in Ghana.

Despite the major contributions of the study to knowledge, the inability to focus on smart or resilient cities (the alternative development of cities currently embraced as well by researchers and policy makers) was a key limitation of the study. The study was limited in geographical scope with Ghana as the study area rendering its limited power to generalize 
within the developing countries context. Nonetheless, the lessons could be adapted for promoting green cities development in other countries that share similar characteristics with Ghana. Furthermore, future research is recommended to focus on smart/resilient cities whiles broaden its geographical scope to consider more countries. A further study could incorporate the verbatim perspectives of stakeholders in city development through a qualitative study.

\section{Conflicts of Interests}

The authors declare no conflict of interests. The funders had no role in the design of the study; in the data collection, analysis, or interpretation of data; in the writing of the manuscript, and in the decision to publish the results.

\section{Acknowledgement}

This paper forms part of a large MSc. research project aimed at developing an Apposite Framework for Green Cities Development in Developing Countries. The authors gratefully acknowledge the Ghana Education Trust Fund (GETFund) for funding this research. The authors also appreciatively acknowledge the Department of Construction Technology and Management, KNUST for supporting this research. Special appreciations also go to the Editors and Reviewers whose constructive and invaluable comments and propositions played a pivotal role in noticeably improving the quality of the work.

\section{References}

Ali, Z., and Bhaskar, S. B. (2016). Basic statistical tools in research and data analysis. Indian Journal of Anaesthesia, 60(9), 662. https://doi.org./10.4103/0019-5049.190623 
AlSanad, S. (2015). Awareness, drivers, actions, and barriers of sustainable construction in Kuwait. Procedia engineering, 118 ,

969-983. https://doi.org/10.1016/j.proeng.2015.08.538

Altman, D. G., and Bland, J. M. (2005). Standard deviations and standard errors. Bmj, 331(7521), 903. https://doi.org/10.1136/bmj.331.7521.903

Anzagira, L. F., Badu, E., and Duah, D. (2019). Towards an uptake framework for the green building concept in Ghana: a theoretical review. Resourceedings, 2(1), 57-76. https://dx.doi.org/10.21625/resourceedings.v2i1.452

Ayarkwa, J., Acheampong, A., Wiafe, F., and Boateng, B. E. (2017, April). Factors affecting the implementation of sustainable construction in Ghana: the architect's perspective. In ICIDA 2017-6th International Conference on Infrastructure Development in Africa, $12-14$.

[Online] https://www.researchgate.net/publication/317277282_Factors_Affecting the_Implem entation_of_Sustainable_Construction_in_Ghana_the_Architect's_Perspective

[Accessed 30th July, 2020]

Barthel, P. A. (2016). Morocco in the era of eco-urbanism Building a critical and operational research on an emerging practice in Africa. Smart and Sustainable Built Environment, 5(3), 272-288. https://doi.org/10.1108/SASBE-05-2014-0033

Boquet, K., Froitier, C., Li, J., Xu, K., and Zeng, X. (2020). Eco-districts in France: What tools to ensure goals achievement? Science China Earth Sciences, 1-10. https://doi.org/10.1007/s11430-018-9605-4

Brilhante, O., and Klaas, J. (2018). Green city concept and a method to measure green city performance over time applied to fifty cities globally: Influence of GDP, population size and energy efficiency. Sustainability, 10(6), 2031. https://doi.org/10.3390/su10062031

Chan, A. P. C., Darko, A., Olanipekun, A. O., and Ameyaw, E. E. (2018). Critical barriers to green building technologies adoption in developing countries: The case of Ghana. Journal of cleaner production, 172, 1067-1079. https://doi.org/10.1016/i.jclepro.2017.10.235

Costa, C. S., Erjavec, I. Š., and Mathey, J. (2008). Green Spaces-A Key Resources for Urban Sustainability the Greenkeys Approach for Developing Green Spaces. Urbani Izziv, 19(2), 199-211. [Online] https://www.semanticscholar.org/paper/Green-spaces$\% \mathrm{E} 2 \% 80 \% 93$-a-key-resources-for-urban-The-for-CostaMathey/b260b785cc5020600cc45113d6e683eb4d510019 [Accessed 30th July, 2020]

Darko, A., and Chan, A. P. (2017). Review of barriers to green building adoption. Sustainable Development, 25(3), 167-179. https://doi.org/10.1002/sd.1651

Darko, A., Chan, A. P., Owusu-Manu, D. G., and Ameyaw, E. E. (2017). Drivers for implementing green building technologies: An international survey of 
experts. Journal of cleaner production, 145, 386-394. https://doi.org/10.1016/j.jclepro.2017.01.043

Darko, A., Owusu, E. K., Chan, A. C., and Afari, M. F. (2018, April). Benefits of green building: a literature review. In Cobra Conference. [Online] https://core.ac.uk/download/pdf/79607955.pdf [Accessed 30th July, 2020]

Davidoff, F., Gordon, N., Tarnow, E., and Endriss, K. (2002). A question of response rate. Science Editor, 25(1), 25-26. [Online] https://www.councilscienceeditors.org/wp-content/uploads/v25n1p025-026.pdf

[Accessed 31 March, 2020].

Green Growth Best Practice Initiative. (2014). Green Growth in Practice: Lessons from Country Experiences. Seoul (Global Green Growth Institute). [Online] https://www.greengrowthknowledge.org/resource/green-growth-practice-lessonscountry-experiences [Accessed 31 March, 2020].

Guadagnoli, E., and Velicer, W. F. (1988). Relation of sample size to the stability of component patterns. Psychological bulletin, 103(2), 265-275. https://psycnet.apa.org/doi/10.1037/0033-2909.103.2.265

Hammer, S., Kamal-Chaoui, L., Robert, A. and Plouin, M. (2011). Cities and Green Growth: A Conceptual Framework. OECD Regional Development Working Papers. 8/2011. Paris: OECD. http://dl.ueb.vnu.edu.vn/handle/1247/11925

Haruna, A. I., Oppong, R. A., and Marful, A. B. (2018). Exploring eco-aesthetics for urban green infrastructure development and building resilient cities: A theoretical overview. Cogent Social Sciences, 4(1), 1478492. https://doi.org/10.1080/23311886.2018.1478492

Hoornweg, D., and Freire, M. (2013). Building sustainability in an urbanizing world: A partnership report. [Online] http://hdl.handle.net/10986/18665 [Accessed 17th June, 2020].

Huq, S., Kovats, S., Reid, H., and Satterthwaite, D. (2007). Reducing risks to cities from disasters and climate change. 19(1), 3-15. https://doi.org/10.1177/0956247807078058

Ichimura, M. (2003, January). Urbanization, urban environment and land use: challenges and opportunities. In Asia-Pacific Forum for Environment and Development, Expert Meeting, 23, 1-14. [Online] http://www.kas.de/upload/dokumente/megacities/urbanization_urban_environment_a nd_land_use.pdf [Accessed 17th June, 2020].

Jabareen, Y. R. (2006). Sustainable urban forms: Their typologies, models, and concepts. Journal of planning education and research,26(1), 38-52. https://doi.org/10.1177\%2F0739456X05285119

Jackson-Smith, D., Flint, C. G., Dolan, M., Trentelman, C. K., Holyoak, G., Thomas, B., and Ma, G. (2016). Effectiveness of the drop-off/pick-up survey methodology in different 
neighborhood types. Journal of Rural Social Sciences, 31(3), 35-67. https://egrove.olemiss.edu/jrss/vol31/iss3/3

Johnson, R. B., and Onwuegbuzie, A. J. (2004). Mixed methods research: A research paradigm whose time has come. Educational researcher,33(7), 14-26. https://doi.org/10.3102\%2F0013189X033007014

Kats, G. (2003). Green building costs and financial benefits (p. 1). Boston, MA: Massachusetts Technology Collaborative. [Online] http://www.greenspacebuildings.com/wp-content/uploads/2011/05/Kats-GreenBuildings-Cost.pdf [Accessed 17th June, 2020].

Keivani, R. (2010). A review of the main challenges to urban sustainability. International Journal of Urban Sustainable Development, 1(1-2), 5-16. https://doi.org/10.1080/19463131003704213

Kissi, E., Samuel, A. S., Agyemang, D. Y., Daniel, O., and Caleb, D. (2020a). Identification of factors influencing the pricing of sustainable construction materials in developing countries: views of Ghanaian quantity surveyors. International Journal of Construction Management, 1-10. https://doi.org/10.1080/15623599.2020.1768462

Kissi, E., Ahadzie, D. K., Debrah, C., and Adjei-Kumi, T. (2020b). Underlying strategies for improving entrepreneurial skills development of technical and vocational students in developing countries: using Ghana as a case study. Education + Training. 62(5), 599614. https://doi.org/10.1108/ET-11-2019-0264

Kline, R.B. (2015). Principles and practice of structural equation modelling. Guilford publications. ISBN 9781462523344

Lani, J. (2016). Statistics solutions: Advancement through clarity. Obtenido de [Online] http://www. statisticssolutions. com/theoretical-framework. [Accessed 17th June, 2020].

Leichenko, R. M., and Solecki. W. D. (2005). Exporting the American dream: the globalization of suburban consumption landscapes. Regional Studies 39(2), 241-253. http://dx.doi.org/10.1080/003434005200060080

Leksakundilok, A. (2004). Community participation in ecotourism development in Thailand. The University of Sydney. [Online] https://ses.library.usyd.edu.au/handle/2123/668 [Accessed 1st June, 2020].

Lewis, E. (2015). Green City Development Tool Kit. Asian Development Bank. [Online] http://hdl.handle.net/11540/5151. [Accessed 1st June, 2020].

Liaros, S. (2019). Implementing a new human settlement theory. Smart and Sustainable Built Environment, 9(3), 258-271. https://doi.org/10.1108/SASBE-01-2019-0004

Lindfield, M., and Steinberg, F. (2012). Green cities. Asian Development Bank. ISBN 97892-9092-897-3 
London School of Economies (LSE) (2013). Going Green: How cities are leading the next economy. A global survey and case studies of cities building the green economy. Final report. [Online] https://www.lse.ac.uk/cities/publications/researchreports/Going-Green-How-cities-are-leading-the-next-economy [Accessed 1st June, 2020].

Massey, A., and Miller, S. J. (2006). Tests of hypotheses using statistics. Mathematics Department, Brown University, Providence, RI, 2912, 1-32. [Online] http://www.academia.edu/download/30764428/StatsTests04.pdf [Accessed 1st June, 2020].

Mathers, N., Fox, N., and Hunn, A. (2007). Surveys and Questionnaires. The NIHR RDS for the East Midlands/Yorkshire \& the Humber. [Online] https://www.academia.edu/11450102/The_NIHR_Research_Design_Servic e_for_Yorkshire_and the_Humber_Surveys_and_Questionnaires_Authors [Accessed 1st June, 2020].

Mclntyre, B. D., Herren, H. R., Wakhungu, J., and Watson, R. T. (2009). Global report (No. 338.927 G562). International Assessment of Agricultural Knowledge, Science and Technology for Development, Washington, DC (EUA). ISBN 9781597265393

Mersal, A. (2017). Eco city Challenge and opportunities in transferring a city in to green city. Procedia Environmental Sciences, 37, 22-33. https://doi.org/10.1016/j.proenv.2017.03.010

Muijs, D. (2010). Doing quantitative research in education with SPSS. Sage. ISBN 144624234X, 978144624234

Neville, C. (2007). Effective learning service: Introduction to research and research methods. UK: Bradford University School of Management. [Online] http://www.bradford.ac.uk/academicskills/media/learnerdevelopmentunit/documents/academicskillsresources/writingessaystraditionalacademic/media-30488-en..pdf [Accessed 1st June, 2020].

Onishi, A., Cao, X., Ito, T., Shi, F., and Imura, H. (2010). Evaluating the potential for urban heat-island mitigation by greening parking lots. Urban forestry \& Urban greening, 9(4), 323-332. https://doi.org/10.1016/j.ufug.2010.06.002

Organisation for Economic Co-operation and Development (OECD) (2013). Compact City Policies: A Comparative Assessment, Paris ed.; OECD: Paris, France. [Online] https://www.oecd.org/greengrowth/compact-city-policies-9789264167865en.htm [Accessed 1st June, 2020].

Owusu-Manu, D. G., Debrah, C., Antwi-Afari, P., and Edwards, D. J. (2019, July). Barriers of Project Bond Initiatives in Infrastructure Financing in Ghana. In Construction Industry Development Board Postgraduate Research Conference, 12-21. Springer, Cham. https://doi.org/10.1007/978-3-030-26528-1_2 
Owusu-Manu, D. G., Edwards, D. J., Kukah, A. S., Parn, E. A., El-Gohary, H., and Hosseini, M. R. (2018). An empirical examination of moral hazards and adverse selection on PPP projects. Journal of Engineering, Design and Technology. https://doi.org/10.1108/JEDT-01-2018-0001

Pandey, P., and Pandey, M. M. (2015). Research methodology: Tools and techniques. Romania:

Bridge

Center. [Online] http://www.euacademic.org/BookUpload/9.pdf [Accessed 1st June, 2020].

Prakash, A. (2019). Smart Cities Mission in India: some definitions and considerations. Smart and Sustainable Built Environment. 8(4), 322-337. https://doi.org/10.1108/SASBE$\underline{\text { 07-2018-0039 }}$

Rooshdi, R. R. R. M., Majid, M. Z. A., Sahamir, S. R., and Ismail, N. A. A. (2018). Relative importance index of sustainable design and construction activities criteria for green highway. Chemical Engineering

Transactions, 63,

151-156. https://dx.doi.org:10.3303/CET1863026

Rosenzweig, C., Solecki, W. D., Romero-Lankao, P., Mehrotra, S., Dhakal, S., and Ibrahim, S. A. (Eds.). (2018). Climate change and cities: Second assessment report of the urban climate change research network. Cambridge University Press. ISBN 1316603334, 9781316603338

Ross, A., and Willson, V. L. (2017). One-sample T-test. In Basic and Advanced Statistical Tests, 9-12. Brill Sense. https://brill.com/view/book/edcoll/9789463510868/BP000003.xml

Sandhu, S. C., Singru, R. N., Bachmann, J., Sankaran, V., and Arnoux, P. (2016). GrEEEn solutions for liveable cities. Asian Development Bank. 978-92-9257-351-5 (e-ISBN)

Saunders, M., Lewis, P., and Thornhill, A. (2009). Research methods for business students. Pearson education.

[Online] http://www.academia.edu/download/52155665/Solution_Manual_for_Resea rch_Methods_for_Business_Students_6E.doc [Accessed 1st June, 2020].

Simon, D. (Ed.). (2016). Rethinking sustainable cities: Accessible, green and fair. Policy Press. https://doi.org/10.26530/OAPEN_613676

Tan-Mullins, M. (2018). Who Are Green Cities Actually For? RCC Perspectives, (1), 33-38. [Online] www.jstor.org/stable/26511156 [Accessed 1st June, 2020].

Thomas, D. R. (2006). A general inductive approach for analyzing qualitative evaluation data. American journal of evaluation, 27(2), 237-246. [Online] https://doi.org/10.1177\%2F1098214005283748

United Nations (2018). 2018 revision of world urbanization prospects. [Online] https://population.un.org/wup/ [Accessed 1st June, 2020]. 
Windapo, A. O., and Goulding, J. S. (2015). Understanding the gap between green building practice and legislation requirements in South Africa. Smart and Sustainable Built Environment. 4(1), 67-96. https://doi.org/10.1108/SASBE-01-2014-0002

World Commission on Environment and Development (1987). Our common future-The Brundtland report. Report of the World Commission on Environment and Development. [Online] http://www.environmentandsociety.org/mml/un-worldcommission-environment-and-development-ed-report-world-commissionenvironment-and [Accessed 1st June, 2020].

World Economic Forum (2016). Inspiring Future Cities \& Urban Services Shaping the Future of Urban Development \& Services Initiative. [Online] https://www.weforum.org/reports/inspiring-future-cities-urban-servicesshaping-the-future-of-urban-development-services-initiative [Accessed 1st June, 2020].

Zhang, X., Shen, L., Wu, Y., and Qi, G. (2011). Barriers to implement green strategy in the process of developing real estate projects. The Open Waste Management Journal, 4(1), 33-37. http://dx.doi.org/10.2174/1876400201104010033 